UDC 631.788(477)

DOI: https://doi.org/10.32782/2413-9971/2021-35-12

\author{
Khodova Yana \\ Candidate of Economic Sciences, \\ Senior Lecturer at Department of Transport Management and Logistics \\ Pryazovskyi State Technical University
}

Ходова Я. О.

кандидат економічних наук, доиент кафедри менеджменту транспорту і логістики ДВНЗ «Приазовський державний технічний університет»

\title{
AGRO-INDUSTRIAL SECTOR OF UKRAINE: CURRENT SITUATION, TRENDS AND DEVELOPMENT PROSPECTS
}

Summary. Based on the study of economic literature, its regulatory framework, the issue of conceptual foundations of foreign economic activity of agribusiness enterprises is revealed. The principles of development of the national market of agro-industrial complex of Ukraine as a component of the international market and identification of prospects for its further development are substantiated. The conjuncture of the Ukrainian and world markets of grain crops is studied as well as the analysis of production, supply, consumption and trade in grain in recent years (2009-2019). The analysis of the state of production and consumption of grain crops, the dynamics of export-import of grain crops in Ukraine according to the analysis of data of the international food organization UN FAO and the Agricultural Market Information System AMIS, is carried out. The achievements of agrologistics on a global scale allow them to be introduced into the practice of Ukrainian agribusiness, and thus contribute to the successful development of Ukraine's economy as an independent European state. Thus, the factors restraining the development of agricultural products are identified and directions for increasing the level of competitiveness in the field of agricultural logistics are proposed.

Key words: agrologistics, supply chain, world market, competitiveness, development, conjuncture, agroproducts.

Introduction and problem statement. Today, agrologistics is one of the main sources of reducing costs in agriculture in terms of coordination and integration of processes for managing the supply of raw materials, its processing and delivery of finished products to the consumer. Additional costs are incurred in supply chains in the management of orders and deliveries, warehouses and stocks, transport, etc. Their reduction is the main goal of implementing effective management solutions based on a logistical approach aimed at increasing the competitiveness of agricultural products and agriculture in general [2].
Analysis of recent research and publications. The study of the main problems of logistical support of foreign economic activity in the agricultural sector of Ukraine, as well as ways and methods of their solution are reflected in the works by leading economists A.P. Haidutskyi, P.I. Haidutskyi, T.O. Zinchuk, A.M. Kandyba, S.M. Kvasha, H.O. Kukharska, B.H. Sheleheda and others.

The purpose of this work is the theoretical justification of the current state of the national market of agro-industrial complex of Ukraine as a component of the international market and identification of prospects for its further development. 
Results of the research. Cereals are one of the largest commodity positions in the world agri-food market, traded by many countries, including domestic agricultural exporters. Therefore, to some extent, it naturally draws special attention to its condition and analysis of the dynamics of development, monitoring of trends and tendencies. It is well known that the main grain crops in the world are wheat, corn and rice, which form the strategic food basket of mankind [1].

Analysis of the latest report «Summary of demand and supply of grain», which is periodically published for the general public by the Food and Agriculture Organization of the United Nations (FAO) from March 7, 2019, according to expert estimates, world grain production last year amounted to 2609 million tons (including rice polished). This is a total of 2.8 million tons less than in the previous forecast for February. The downward revision is almost entirely due to the decline in the assessment of corn production in the United States and generally reflects the overall decline in world grain production compared to the previous year. Global rice production in 2018, according to forecasts, should reach 515 million tons, which is $1.6 \%$ higher than in 2017, and reach a historically record level (Table 1-2).

According to cereals this year, according to the analysis of FAO forecast data, world production will reach about 757.4 million tons. At the same time, annual production will exceed last year's figures by $4 \%$, but will not reach the record level of 2017 [4]

FAO experts in March 2019 also revised downwards the estimate of grain production last year. As a result, the forecast for total grain consumption in the world in 2018-2019 was reduced to 2652 million tons, largely due to the expected reduction in feed use of major cereals, especially in the United States. However, in general, world consumption of feed grain in 2018-2019 MY will be 2\% higher than the previous season, and rice and wheat may increase, respectively, by $0.9 \%$ and $0.5 \%$.

The volume of world grain trade in 2019-2020 will reach about 413.4 million tons, which is 8.2 million tons less than in the same period 2018-2019. The five largest grain exporters in the world are Australia, Argentina, the EU, Canada and the United States; the main exporters of wheat are Argentina, Australia, Canada, the EU, Kazakhstan, the Russian Federation, Ukraine and the United States; the main rice exporters are Vietnam, India, Pakistan, the United States and Thailand.

The structure of world grain trade is characterized by an almost uniform distribution between feed products (corn, barley, sorghum, oats and other crops) and wheat, as well as a small share of rice (Figure 1). Grain consumption worldwide has been growing steadily in recent years, which is one of the factors in increasing its production and trade.
According to the analysis of the data of the International Food Organization (FAO) and the Agricultural Market Information System (AMIS), domestic grain exports to the world market will be a record in 2020-2021 marketing period and will reach about 48 million tons, which is, according to our estimates, almost $12 \%$ of worldwide indicator (Table 4 ).

This was made possible primarily by the formation of a high supply of grain in the domestic market, which is almost 75 million tons, due to its record harvest last year. In general, over the past 10 years, domestic grain exports to the world agri-food market have more than doubled, which is a significant trend in its development in the context of global integration of agriculture after accession to the WTO in 2008. During the analyzed period, the annual demand for grain in the world increased by an average of 30-50 million tons, which opens up significant prospects for the domestic agricultural sector of the economy to increase its production to 100 million tons.

Achieving these indicators is quite possible due to further priority development and state support of domestic agricultural science. In particular, the development of selection of varieties and hybrids of cereals in the direction of increasing their yield and drought resistance, as well as improving cultivation technology, optimizing the use of mineral fertilizers and the transition of many farms to an integrated plant protection system.

This was made possible primarily by the formation of a high supply of grain in the domestic market, which is almost 75 million tons, due to its record harvest last year. In general, over the past 10 years, domestic grain exports to the world agri-food market have more than doubled, which is a significant trend in its development in the context of global integration of agriculture after accession to the WTO in 2008.

During the analyzed period, the annual demand for grain in the world increased by an average of 30-50 million tons, which opened for the domestic agricultural sector of the economy significant prospects to increase its production to 100 million tons. In particular, it was due to the development of selection of varieties and hybrids of cereals in the direction of increasing their yield and drought resistance, as well as improving cultivation technology, optimizing the use of mineral fertilizers and the transition of many farms to an integrated plant protection system.

The situation on the world grain market in general is characterized by the persistence of high price volatility and their variability due to changes in economic conditions and is also due to the influence of weather conditions.

The average value of the FAO grain price index in February this year is 169 points, which is only slightly higher than in January and 8 points $(4.7 \%)$ higher than the same level in

Table 1

Conjuncture of the world market of grain crops

\begin{tabular}{|c|c|c|c|c|c|c|c|}
\hline \multirow{2}{*}{$\mathbf{M} / \mathbf{P}$} & Production & Offer & Consumption & Trade & $\begin{array}{c}\text { Inventories at } \\
\text { the end of the } \\
\text { period }\end{array}$ & $\begin{array}{c}\text { Global indicator } \\
\text { of the ratio of } \\
\text { inventories and } \\
\text { consumption }\end{array}$ & $\begin{array}{c}\text { The ratio of } \\
\text { stocks of major } \\
\text { exporters to } \\
\text { their use }\end{array}$ \\
\cline { 2 - 8 } & \multicolumn{7}{|c|}{ million tons } \\
\hline $2009 / 10$ & 2260.6 & 2795.8 & 2223.1 & 279.4 & 572.8 & 25.2 & 20.3 \\
\hline $2010 / 11$ & 2249.0 & 2821.7 & 2273.0 & 289.9 & 546.8 & 23.6 & 18.1 \\
\hline $2011 / 12$ & 2340.9 & 2887.7 & 2317.3 & 322.5 & 566.5 & 24.5 & 18.4 \\
\hline $2012 / 13$ & 2294.1 & 2860.6 & 2313.2 & 318.2 & 558.1 & 23.1 & 17.2 \\
\hline $2013 / 14$ & 2526.0 & 3084.2 & 2418.8 & 364.2 & 636.3 & 25.5 & 18.6 \\
\hline $2014 / 15$ & 2572.5 & 3208.9 & 2493.7 & 376.9 & 711.7 & 28.3 & 19.1 \\
\hline $2015 / 16$ & 2541.3 & 3253.1 & 2513.6 & 392.7 & 734.3 & 28.6 & 16.8 \\
\hline $2016 / 17$ & 2612.6 & 3346.8 & 2570.6 & 405.2 & 772.8 & 29.6 & 17.6 \\
\hline $2017 / 18$ & 2657.8 & 3430.6 & 2615.0 & 421.6 & 809.7 & 30.5 & 18.0 \\
\hline $2018 / 19$ & 2608.6 & 3418.3 & 2651.5 & 413.4 & 766.5 & & 28.3 \\
\hline
\end{tabular}


Table 2

The situation on the world wheat market

\begin{tabular}{|c|c|c|c|c|c|c|c|}
\hline \multirow{2}{*}{$\mathbf{M} / \mathbf{P}$} & Production & Offer & Consumption & Trade & $\begin{array}{c}\text { Inventories at } \\
\text { the end of the } \\
\text { period }\end{array}$ & $\begin{array}{c}\text { Global indicator } \\
\text { of the ratio of } \\
\text { inventories and } \\
\text { consumption }\end{array}$ & $\begin{array}{c}\text { The ratio of } \\
\text { stocks of major } \\
\text { exporters to } \\
\text { their use }\end{array}$ \\
\cline { 2 - 9 } & & \multicolumn{3}{|c|}{ million tons } \\
\hline $2009 / 10$ & 684.8 & 865.0 & 655.0 & 130.9 & 209.8 & 32.0 & 22.8 \\
\hline $2010 / 11$ & 651.0 & 860.8 & 656.8 & 129.8 & 206.0 & 29.7 & 21.9 \\
\hline $2011 / 12$ & 697.8 & 903.8 & 694.7 & 149.0 & 203.9 & 29.9 & 18.8 \\
\hline $2012 / 13$ & 657.0 & 860.8 & 683.1 & 143.4 & 182.9 & 26.5 & 14.9 \\
\hline $2013 / 14$ & 712.8 & 895.7 & 690.2 & 159.5 & 196.5 & 27.6 & 15.7 \\
\hline $2014 / 15$ & 732.4 & 928.9 & 712.5 & 156.3 & 217.4 & 30.6 & 18.4 \\
\hline $2015 / 16$ & 734.3 & 951.7 & 710.1 & 167.0 & 236.2 & 32.2 & 18.0 \\
\hline $2016 / 17$ & 756.9 & 993.1 & 734.5 & 176.3 & 254.5 & 34.5 & 19.9 \\
\hline $2017 / 18$ & 759.4 & 1014.0 & 737.8 & 176.9 & 275.3 & 37.1 & 20.8 \\
\hline $2018 / 19$ & 728.3 & 1003.6 & 741.8 & 171.0 & 264.7 & 35.0 & 17.2 \\
\hline
\end{tabular}

Table 3

Conjuncture of the world market of grain for feed use (grain of corn, barley, sorghum, oats and other crops)

\begin{tabular}{|c|c|c|c|c|c|c|c|}
\hline \multirow[t]{2}{*}{$\mathbf{M} / \mathbf{P}$} & Production & Offer & Consumption & Trade & $\begin{array}{c}\text { Inventories at } \\
\text { the end of the } \\
\text { period }\end{array}$ & $\begin{array}{l}\text { Global indicator } \\
\text { of the ratio of } \\
\text { inventories and } \\
\text { consumption }\end{array}$ & $\begin{array}{l}\text { The ratio of } \\
\text { stocks of major } \\
\text { exporters to } \\
\text { their use }\end{array}$ \\
\hline & \multicolumn{5}{|c|}{ million tons } & & \\
\hline $2009 / 10$ & 1122.1 & 1361.6 & 1120.9 & 116.2 & 242.1 & 21.0 & 16.2 \\
\hline $2010 / 11$ & 1131.1 & 1373.2 & 1157.0 & 123.3 & 214.0 & 18.6 & 11.3 \\
\hline $2011 / 12$ & 1159.7 & 1373.7 & 1155.1 & 132.9 & 220.2 & 19.1 & 11.3 \\
\hline $2012 / 13$ & 1148.5 & 1368.7 & 1155.8 & 134.5 & 218.7 & 17.7 & 8.9 \\
\hline $2013 / 14$ & 1318.2 & 1537.0 & 1244.1 & 159.0 & 273.4 & 21.2 & 11.0 \\
\hline $2014 / 15$ & 1345.6 & 1618.9 & 1290.1 & 175.5 & 325.4 & 24.9 & 14.3 \\
\hline $2015 / 16$ & 1314.6 & 1639.9 & 1308.9 & 184.3 & 331.1 & 24.8 & 12.6 \\
\hline $2016 / 17$ & 1353.7 & 1684.8 & 1337.0 & 180.7 & 349.9 & 25.5 & 14.0 \\
\hline $2017 / 18$ & 1391.6 & 1741.5 & 1372.5 & 196.6 & 361.9 & 25.8 & 15.2 \\
\hline $2018 / 19$ & 1365.4 & 1727.3 & 1400.5 & 195.2 & 324.2 & 22.6 & 13.4 \\
\hline
\end{tabular}

Situation of the grain market of Ukraine and its impact on global trade

Table 4

\begin{tabular}{|c|c|c|c|c|c|c|}
\hline $\mathbf{M} / \mathbf{P}$ & $\begin{array}{c}\text { Production, } \\
\text { million tons }\end{array}$ & $\begin{array}{c}\text { Offer, million } \\
\text { tons }\end{array}$ & $\begin{array}{c}\text { Consumption, } \\
\text { million tons }\end{array}$ & $\begin{array}{c}\text { Trade (export), } \\
\text { million tons }\end{array}$ & $\begin{array}{c}\text { Trade (import), } \\
\text { million tons }\end{array}$ & $\begin{array}{c}\text { Inventories at the } \\
\text { end of the period, } \\
\text { million tons }\end{array}$ \\
\hline $2009 / 10$ & 45.616 & 54.821 & 26.975 & 20.965 & 0.143 & 7.023 \\
\hline $2010 / 11$ & 38.930 & 45.952 & 27.133 & 12.336 & 0.227 & 6.711 \\
\hline $2011 / 12$ & 56.412 & 63.123 & 29.956 & 21.827 & 0.205 & 11.544 \\
\hline $2012 / 13$ & 45.879 & 57.423 & 26.711 & 23.204 & 0.176 & 7.684 \\
\hline $2013 / 14$ & 62.899 & 70.582 & 27.255 & 32.600 & 0.219 & 10.945 \\
\hline $2014 / 15$ & 63.653 & 74.598 & 26.979 & 34.850 & 0.163 & 12.932 \\
\hline $2015 / 16$ & 59.941 & 72.873 & 24.001 & 39.635 & 0.179 & 9.416 \\
\hline $2016 / 17$ & 65.529 & 74.945 & 23.196 & 44.669 & 0.219 & 7.300 \\
\hline $2017 / 18$ & 60.827 & 68.127 & 22.264 & 40.071 & 0.227 & 6.018 \\
\hline $2018 / 19$ & 69.033 & 75.051 & 21.582 & 47.907 & 0.246 & 5.807 \\
\hline
\end{tabular}

February 2018. Of the major cereals, the price of corn rose the most, primarily due to higher export quotations in the United States due to concerns about delays in its supply to the market.

Despite the fact that at the beginning of the month the reservations on the formation of the supply of wheat supported prices, the reduction in trade activity significantly affected their decline, and eventually led to a fall. The FAO rice price index remained stable as low demand restrained the corresponding increase in price quotations.

For domestic agro-exporters, the price situation on the world market in early January-February 2019 was quite favorable (Figure 1). Dynamics of crop production as of September 1, 2020, thousand quintals (Figure 2).

In particular, it is estimated that the maximum increase in the value of domestic exports per 1 ton of products was recorded for oats (90.67 USD, or $141.6 \%$ to its level in 2018 ), barley (33.47 USD, or $117.7 \%$ last year) and wheat (240.78 USD, or $113.5 \%$ of last year's level). These crops, according to the analysis of customs statistics for the incomplete first quarter of 2019, were the most profitable to export.

Analyzing the current state of agrologistics, it should be noted that the difficulties in organizing and managing logistics 


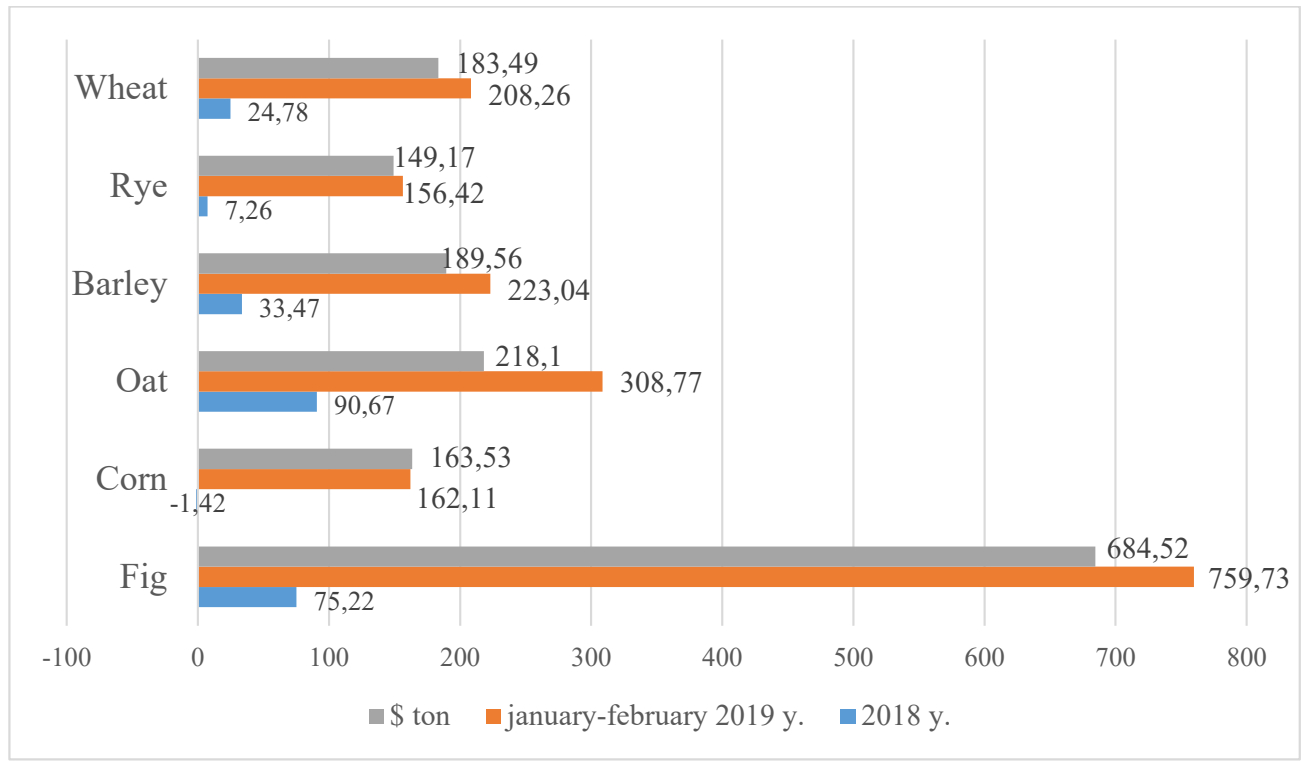

Figure 1. Weighted average export price of 1 ton of major domestic cereals in January-February 2019 and for 2018 in general (in USD)

activities in agricultural enterprises are the lack of technical capabilities in most agricultural enterprises to work effectively with information flows. More than $70 \%$ of agricultural enterprises do not have the necessary computer equipment, and $90 \%$ of enterprises use traditional information processing technologies [3].

Some experts believe that the opportunity for Ukraine to become a regional logistics center in the next 10 years is almost unrealistic. Ukraine's trade and transit potential is huge, but in order to implement it, it is necessary to make every effort not only for agricultural enterprises, but also for the state. They consider legal uncertainty with land ownership, difficulties in obtaining building permits, bureaucracy and corruption to be the main deterrents.

According to practical logistics experts, the main factors influencing the activities in the field of agricultural logistics today are the following: - market conditions and trends present in customer markets, which in turn reflect the current purchasing power of consumers; - unemployment rate; - stability of the national currency; - investment attractiveness of the country and other macroeconomic factors. On the other hand, the level of service in logistics is largely due to the quality of infrastructure, efficient regulation, taxation, transparency of customs procedures, education and training system, the degree of integration into European and global supply chains, etc. [3].

Conclusions. Thus, increasing the level of competitiveness in the field of agricultural logistics and expanding prospects can be achieved by:

- reforming the agricultural sector and ensuring an appropriate regulatory framework governing the work of logistics companies;

- liberalization and improvement of legislative norms in order to bring them closer to the best European practices; adoption of a program for the development of agrologistics following the example of the world's leading countries;

- transparency of state regulation of the industry;

- adoption of an appropriate logistics financing system;

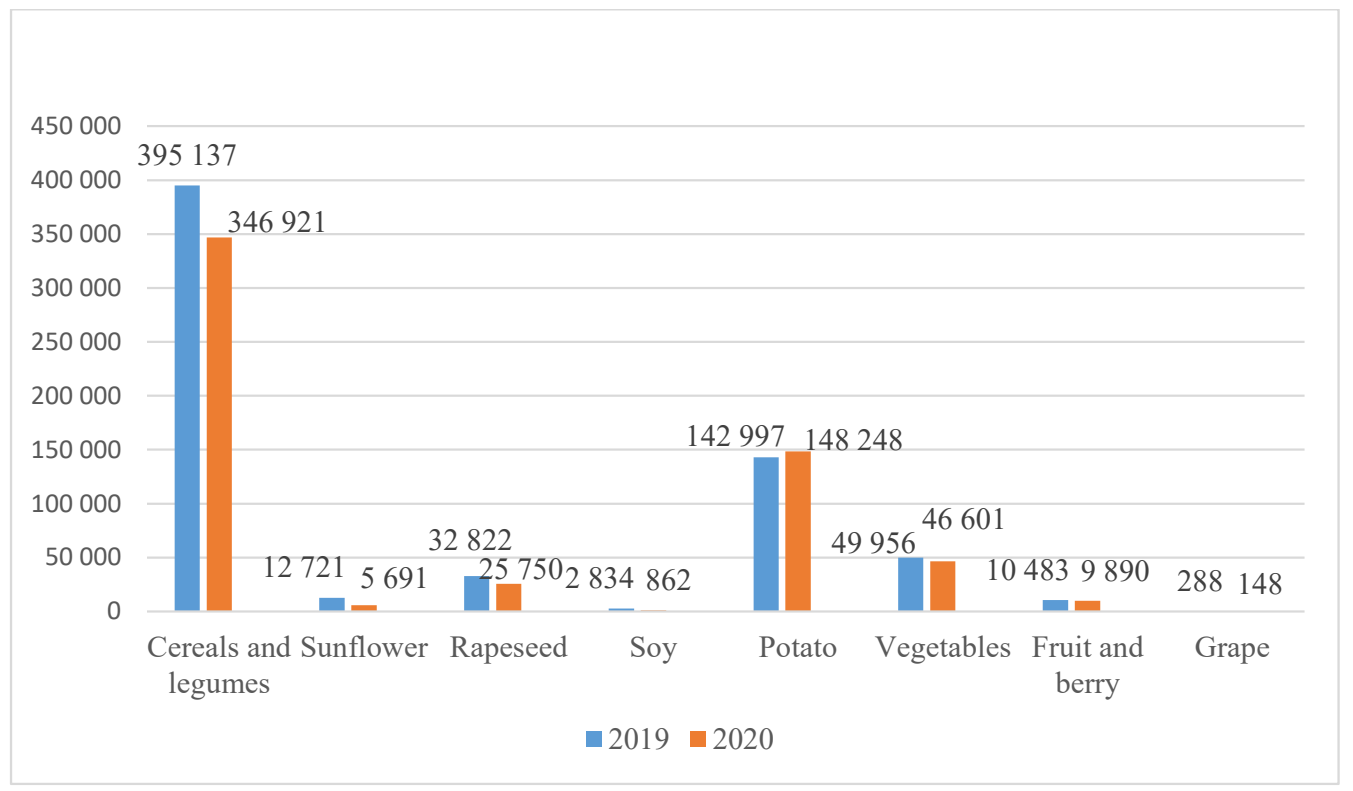

Figure 2. Dynamics of crop production as of 01.09.2020, thousand quintals 
-attracting private investment in the development of the industry, improving the investment attractiveness of the logistics sector by introducing special tax regimes, customs tariffs at enterprises for certain periods (1-3 years from the establishment);

- providing logistics companies with highly qualified specialists; - creation and use of adequate information systems to support agricultural logistics, providing logistics companies with a proper digital cartographic database, programs for them, etc.

Acquaintance with the achievements of agrologistics on a global scale allows to introduce them into the practice of Ukrainian agribusiness, and thus contribute to the successful development of Ukraine's economy as an independent European state.

\section{References:}

1. Khodova Y.O. (2019) Kompleksna systema zbutovoho lohistychnoho menedzhmentu na promyslovomu pidpryiemstvi [Complex system of sales logistics management at an industrial enterprise]. Molodyi vchenyi, vol. 5, pp. 251-254.

2. Khodova Y.O. (2018) Vyznachennia priorytetnykh napriamkiv rozvytku transportno-lohistychnoi systemy Ukrainy: yevropeiskyi vector [Determining the priority areas of development of the transport and logistics system of Ukraine: the European vector]. Molodyi vchenyi, vol. 5, pp. 337-342.

3. Kontseptsiia derzhavnoi tsilovoi prohramy rozvytku ahrarnoho sektoru ekonomiky na period do 2021 roku (2019). Available at: https://zakon.rada.gov.ua/laws/show/1437-2015-\%D1\%80\#n9 (accessed 17 February 2021).

4. Tsili staloho rozvytku 2016-2030 (2016). Available at: http://www.un.org.ua/ua/tsili-rozvytku-tysiacholittia/tsili-staloho-rozvytku (accessed 17 February 2021).

\section{Список використаних джерел:}

1. Ходова Я.О. Комплексна система збутового логістичного менеджменту на промисловому підприємстві. Молодий вчений. 2019. Випуск 5. С. 251-254.

2. Ходова Я.О. Визначення пріоритетних напрямків розвитку транспортно-логістичної системи України: європейський вектор. Молодий вчений. 2018. Випуск 5. С. 337-342.

3. Концепція державної цільової програми розвитку аграрного сектору економіки на період до 2021 року. URL: http://search.ligazakon.ua/1_doc2.nsf/link1/MU92301.html (дата звернення: 17.02.2021).

4. Ц Цілі сталого розвитку 2016-2030 URL: http://www.un.org.ua/ua/tsili-rozvytku-tysiacholittia/tsili-staloho-rozvytku (дата 3вернення: 17.02.2021).

\section{АГРОПРОМИСЛОВИЙ СЕКТОР УКРАЇНИ: СУЧАСНИЙ СТАН, ТЕНДЕНЦІЇ ТА ПЕРСПЕКТИВИ РОЗВИТКУ}

Анотація. Розвиток агропромислового комплексу України та його провідних галузей $є$ пріоритетним, так як дає можливість забезпечити продовольчими товарами населення, сировиною промисловість та експортними товарами зовнішню торгівлю. Агрологістика відіграє все важливішу роль як у підвищенні ефективності всього агропромислового комплексу, так і його внутрішньо та зовнішньо галузевих зв'язків у межах так званого харчового логістичного ланцюжка. Питання розвитку агропромислового комплексу стосується не лише національного рівня, тобто внутрішніх ринкових відносин, а й зовнішньоекономічних відносин, саме тому агропромисловий сектор займає провідне місце на міжнародній арені. У статті детально проаналізовано сучасний стан агрологістичної системи України, підкреслені основні негативні тенденції, які на сьогодні склалися в аграрному секторі та охарактеризовані основні аспекти логістичної діяльності, характерні для підприємств агропромислового комплексу. Визначено головні чинники, які стримують розвиток АПК країни та висвітлено можливі шляхи і способи підвищення ефективності вітчизняної агрологістики. На основі дослідження економічної літератури та законодавчо-нормативної бази економічної літератури розкрито питання концептуальних засад зовнішньоекономічної діяльності підприємств агробізнесу. Обгрунтовано засади розвитку національного ринку АПК України як складової міжнародного ринку та виявлення перспективи щодо його подальшого розвитку. Досліджено кон'юнктуру українського та світового ринків зернових культур. Здійснено аналіз виробництва, пропозиції, споживання і торгівлі зерновими за останні роки (2009-2019). Проведено аналіз стану виробництва та споживання зернових культур, динаміки експорту-імпорту зернових культур в Україні згідно з аналізом даних міжнародної продовольчої організації ООН FАО і системи інформаційного забезпечення ринків сільськогосподарської продукції AMIS. Досягненнями агрологістики у світовому мірилі дозволяє впровадити їх у практику українського агробізнесу, і тим самим сприяти успішному розвитку економіки України як незалежної європейської держави. Таким чином, визначено фактори, що стримують розвиток сільськогосподарської продукції та запропоновано напрями підвищення рівня конкурентоспроможності у галузі аграрної логістики.

Ключові слова: агрологістика, ланцюг поставок, світовий ринок, конкурентоспроможність, розвиток, кон'юнктура, агропродукти.

\section{АГРОПРОМЫШЛЕННЫЙ СЕКТОР УКРАИНЫ: СОВРЕМЕННОЕ СОСТОЯНИЕ, ТЕНДЕНЦИИ И ПЕРСПЕКТИВЫ РАЗВИТИЯ}

Аннотация. На основе исследования экономической литературы и нормативно-правовой базы экономической литературы раскрыты вопросы концептуальных основ внешнеэкономической деятельности предприятий агробизнеса. Обоснованы принципы развития национального рынка АПК Украины как составляющей международного рынка и изучение перспективы для его дальнейшего развития. Исследована конъюнктуру украинского и мирового рынков зерновых культур. Осуществлен анализ производства, предложения, потребления и торговли зерновыми за последние годы (2009-2019). Проведен анализ состояния производства и потребления зерновых культур, динамики экспорта-импорта зерновых культур в Украине согласно анализу данныХ международной продовольственной организации ООН FАО и системы информационного обеспечения рынков сельскохозяйственной продукции AMIS. Достижения агрологистики в мировом мериле позволяет внедрить их в практику украинского агробизнеса, и тем самым способствовать успешному развитию экономики Украины как независимого европейского государства. Таким образом, определены факторы, сдерживающие развитие сельскохозяйственной продукции и предложены направления повышения конкурентоспособности в области аграрной логистики.

Ключевые слова: агрологистика, цепь поставок, мировой рынок, конкурентоспособность, развитие, конъюнктура, агропродукты. 